\title{
Separation of Molybdenum Isotopes at Supercritical Fluid Extraction with Carbon Dioxide in a Vertical Gradient Field of Temperatures
}

\author{
Boris Viktorovich Borts ${ }^{1}$, Stella Fedorovna Skoromnaya' ${ }^{1}$, Viktor Ivanovich Tkachenко1,2 \\ ${ }^{1}$ NSC Kharkov Institute of Physics and Technology, NAS of Ukraine, Kharkov, Ukraine \\ ${ }^{2}$ V. N. Karazin Kharkiv National University, Kharkov, Ukraine \\ Email: tkachenko@kipt.kharkov.ua
}

How to cite this paper: Borts, B.V., Skoromnaya, S.F. and Tkachenко, V.I. (2020) Separation of Molybdenum Isotopes at Supercritical Fluid Extraction with Carbon Dioxide in a Vertical Gradient Field of Temperatures. Open Journal of Metal, 10, 1-15.

https://doi.org/10.4236/ojmetal.2020.101001

Received: February 11, 2020

Accepted: March 15, 2020

Published: March 18, 2020

Copyright $\odot 2020$ by author(s) and Scientific Research Publishing Inc. This work is licensed under the Creative Commons Attribution International License (CC BY 4.0).

http://creativecommons.org/licenses/by/4.0/

\begin{abstract}
Separation of molybdenum isotope complexes by supercritical fluid extraction (SFE) with carbon dioxide was studied experimentally. The extraction of molybdenum isotope complexes was carried out in the updated extraction chamber (reactor) of the SFE-U installation, which provided an initial pressure of $P \leq 20 \mathrm{MPa}$ at constant temperatures of the upper $\mathrm{T}_{1}=35^{\circ} \mathrm{C}$ and bottom $\mathrm{T}_{2}=45^{\circ} \mathrm{C}$ flanges. The device, through which the eluent was discharged, involved a set of four thin tubes of different lengths located inside the reactor. The axes of the tubes and the reactor are parallel and the tubes are equally spaced circumferentially inside the reactor. The extract was removed from each tube through channels isolated from each other and located in the bottom flange with cylindrical expansion, in which several layers of filter paper were placed. After passing through the filters the extract entered a restrictor designed to remove the eluent from the reactor. The initial pressure of carbon dioxide and the holding time of the extract were specified in the experiments. The level of the eluent sampling was set by the lengths of the tubes depending on the reactor height. A method of producing molybdenum complexes was described. It was experimentally shown that at an initial pressure of $20 \mathrm{MPa}$ and a given holding time a difference from the natural content of Mo isotopes for given heights of extract sampling depending on the reactor height was observed in extracts removed through filters. The ranges of deviation of the content of molybdenum isotopes in extracts from natural one were determined.
\end{abstract}




\section{Keywords}

Carbon Dioxide, Supercritical Fluids, Extraction, Molybdenum, Isotopes, Separation

\section{Introduction}

In view of various practical applications, there is a problem of separation and extraction of isotopes of chemical elements. A large number of scientific and technical literature is devoted to separation of iotopes of chemical elements. First of all, we should mention the problem of separation of natural uranium isotopes. It is of great practical interest for nuclear fuel production [1]-[7].

Recently, along with the problem of separation of uranium isotopes there is a problem of extraction of isotopes of chemical elements for use in nuclear medicine which deals with application of radionuclide pharmaceuticals in diagnosis and treatment of various diseases [8].

To assess the scale of the global use of radioisotopes we give the information on the United States [9] where about 130 radiodiagnostic methods in vivo and about 60 radiodiagnostic methods in vitro are used, which exceeds the domestic capabilities by several times. The number of radionuclide studies per 1000 people per year in Russia is 7, while in Austria-19, in Japan-25 and in the USA-40. In Ukraine, the number of studies per 1000 people per year is up to 20 [10] and this is only the lower border of the European level (20 - 50).

Thus, with a growing number of radionuclide studies by $7 \%-14 \%$ per year [11] there is a need to increase the production of radioisotope ${ }^{99 m} \mathrm{Tc}$ obtained from ${ }^{99}$ Mo [12] [13].

The unstable isotope ${ }^{99}$ Mo occupies one of the first places in the list of radioisotopes and its use in medical practice is well studied [12]. The isotope ${ }^{99 m}$ Tc produced from ${ }^{99}$ Mo as a result of $\beta$ and $\gamma$ decay is included in various pharmaceuticals used in medical diagnostics to visualize the human internal organs: thyroid and salivary glands; heart and large vessels; skeleton; brain tumors; genitourinary organs, etc.

The start of production and organizing the application of ${ }^{99 m} \mathrm{Tc}$ isotope in Ukraine are relevant objectives due to the large number of cancers compared to world standards. [14]. Therefore, the isotope ${ }^{99 m} \mathrm{Tc}$ is an extremely necessary means for detecting cancer at an early stage.

Along with traditional methods for producing the isotope ${ }^{99 m} \mathrm{Tc}$ in Ukraine [13], there is an alternative method based on new physical principles. The basis of this method is the recently developed technology for producing molybdenum complexes and its isotope complexes by supercritical fluid extraction with carbon dioxide $\left(\mathrm{SFE}-\mathrm{CO}_{2}\right)$ [15] [16]. In this technology, molybdenum was extracted with tributyl phosphate from nitric acid solutions [15] [16]. It shows a rather low efficiency of molybdenum extraction due to its low solubility in dilute nitric ac- 
id, as well as due to availability of molybdenum in nitric acid solutions in the form of molybdenum acids of various compositions.

In [17], the redistribution of the isotopic composition of natural uranium ${ }^{235} \mathrm{U}$ in natural in supercritical carbon dioxide $\left(\mathrm{SC}-\mathrm{CO}_{2}\right)$ experimentally is investigated. A diagram and description of the principle work of the experimental setup reactor are shown. A method for sample preparation of samples of granite, containing natural uranium, and the order of extraction are described. The conclusion that the spatial redistribution of isotopes ${ }^{235} \mathrm{U}$ in $\mathrm{SC}-\mathrm{CO}_{2}$ based on the analysis of gamma spectra of extracts is made. It is shown that for certain parameters of SC- $\mathrm{CO}_{2}$ the concentration of the isotope ${ }^{235} \mathrm{U}$ is distributed unevenly in the reactor height: its maximum is near the heated lower flange and decreases with approaching to the top, the colder the flange of the reactor. The separation factor ${ }^{235} \mathrm{U}$ isotope in $\mathrm{SC}-\mathrm{CO}_{2}$ could be a value near 1.2 is concluded.

In [18], the models and analytical solutions extraction of ${ }^{235} \mathrm{U}$ and ${ }^{238} \mathrm{U}$ isotopes complexes in the presence of microdroplets of water in the homogeneous temperature field or in the heated from bellow layer of the $\mathrm{SC}-\mathrm{CO}_{2}$ are suggested. A homogeneous temperature field shows that the effectiveness of SFE with carbon dioxide complexes of uranium isotopes reaches a maximum at the limit of water solubility in $\mathrm{SC}-\mathrm{CO}_{2}$. Theoretical calculations have shown that the maximum concentration of ${ }^{235} \mathrm{U}$ isotope complexes in the heated from below $\mathrm{SC}-\mathrm{CO}_{2}$ layer reaches $1.2 \%$ and observed near the heated bottom of layer. The order of the fulfillment of the SFE with carbon dioxide, in which the concentration of the ${ }^{235} \mathrm{U}$ isotope complexes is higher than the natural value, is described.

In [19], the extraction of molybdenum acetylacetonate and its isotopes by the $\mathrm{SFE}-\mathrm{CO}_{2}$ method was studied. The type of modifier, the time of fluid holding and the pressure in the reactor for the most efficient extraction of molybdenum and its isotopes were determined. A series of experiments for extraction of molybdenum isotope complexes in the updated SFE-U installation at a constant pressure value of $\mathrm{P}=20 \mathrm{MPa}$ and at constant temperatures of the bottom $\mathrm{T}_{2}=$ $45^{\circ} \mathrm{C}$ and upper $\mathrm{T}_{1}=35^{\circ} \mathrm{C}$ reactor flanges was carried out. In the experiments, the extract holding time and the height level of eluent sampling from the reactor were changed. The effect of deviation of the content of Mo isotopes from natural one in the eluent depending on the temperature gradient, holding time and height sampling was described.

In this paper, we continued the study of the extraction of molybdenum acetylacetonate and its isotopes by the $\mathrm{SFE}-\mathrm{CO}_{2}$ method with a new extract sampling device allowing us to obtain test samples differentially according to the reactor height.

\section{The Idea, Materials and Updated Reactor for Extraction of Molybdenum Isotopes}

The idea of the experiments is to establish the fact of an uneven distribution of molybdenum isotopes in a vertical gradient temperature field at $\mathrm{SFE}-\mathrm{CO}_{2}$ which 
is set in the reactor after holding the fluid for 0.5 hours.

Materials. Molybdenum acid (LRW) was used as the original source of molybdenum. The extraction solution was obtained in a Soxhlet apparatus using $100 \mathrm{ml}$ of acetylacetone (CP) and $10 \mathrm{~g}$ of molybdenum acid powder. Molybdenum acid powder was poured into a filter paper bag and placed in a glass sleeve. The sleeve was located in the center of the apparatus. After 20 cycles of Soxhlet apparatus operation, the upper vessel was completely filled with distilled acetylacetone and the extract remaining in the lower flask was extracted for further experiments. The concentration of molybdenum solution in acetylacetone obtained for SFE- $\mathrm{CO}_{2}$ was about $25 \mathrm{mg} / \mathrm{ml}$.

\section{Reactor for Extraction of Molybdenum Isotopes}

The experiments on study of SFE- $\mathrm{CO}_{2}$ of complexes of molybdenum isotopes were carried out on a laboratory facility for supercritical fluid extraction SFE-U in which, unlike [17], another type of device was used for extract removing. The general schematic arrangement of reactor elements is shown in Figure 1.

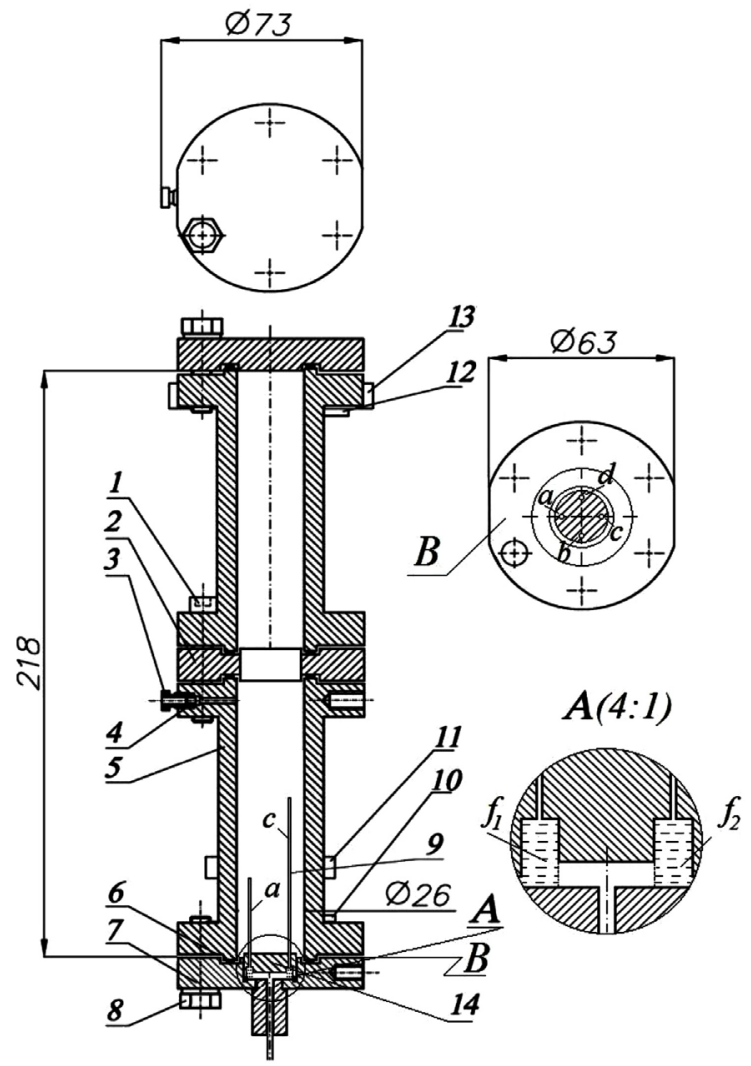

Figure 1. General schematic arrangement of reactor elements. 1. Bolt. 2. Middle flange. 3. Fitting. 4. Rubber sealer. 5. Housing. 6. Filler. 7. Bottom flange. 8. Bolt. 9. Tube c. 10. Temperature sensor of the bottom flange. 11. Heating element of the bottom flange 12. Temperature sensor of the upper flange 13. Heating element of the upper flange. 14. Device for extract removing from reactor. 
The general view of the bottom flange and the device for removing the extract from the reactor screwed to the flange is shown in Figure 2.

The pressure of supercritical carbon dioxide in the installation could raise up to $20.0 \mathrm{MPa}$ and the temperature of the bottom and upper flanges of the reactor could be maintained at a given level within the range $30^{\circ} \mathrm{C}-50^{\circ} \mathrm{C}$ using adjustable heaters. In the experiments, the temperature of the bottom flange was set above the temperature of the upper one.

The device for removing the extract from the reactor (14) involves a set of four thin tubes of different lengths (6 in Figure 2) located inside the reactor. The tubes are made of stainless steel of a diameter of $2 \mathrm{~mm}$ and a wall thickness of $0.5 \mathrm{~mm}$. The axes of the tubes are parallel to the axis of the reactor and evenly spaced around a circle of a radius of $6.4 \mathrm{~mm}$ (see cross-section $B$ in Figure 1).

The extract was removed from each tube through cylindrical extensions 4 (Figure 2) isolated from each other and located at the bottom of the device for extract removing 2 (Figure 2). Several layers of filter paper were placed in each of these extensions. After passing through the filters the extract entered the restrictor hole 5 through the radial channels 7 and then into the receiving tank of pressure corresponded to atmospheric.

In the experiments, the initial pressure of carbon dioxide was $20 \mathrm{MPa}$ and the extract holding time was of the order of 0.5 hours. The level of the eluent sampling according to the height of the reactor was set by the lengths of the tubes a, $\mathrm{b}, \mathrm{c}, \mathrm{d}$ at a reactor height of $\mathrm{L}=21.8 \mathrm{~cm}$.

\section{Procedure for Extraction of Molybdenum Complexes by SFE- $\mathrm{CO}_{2}$ Method}

The extraction at the SFE-U installation with a reactor, the schematic arrangement

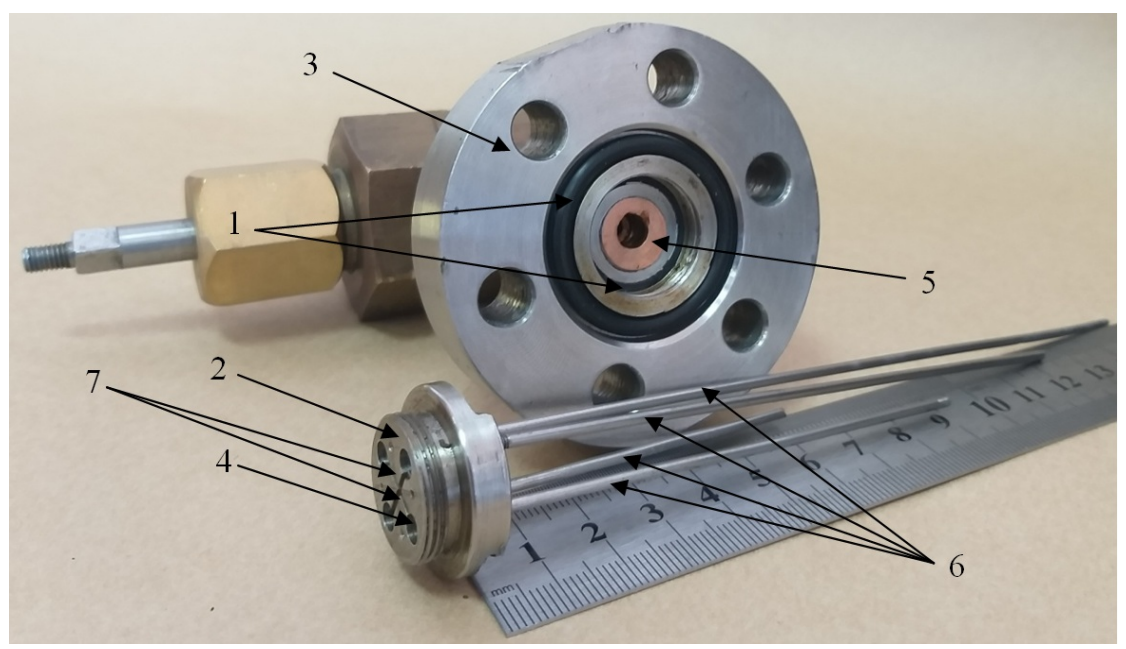

Figure 2. General view of the device for extract removing from the reactor. 1. Rubber sealers. 2. Device for the extract removing (14 in Figure 1, $A$-axial section). 3. Bottom flange ( $B$-cross section from above.. 4. Cylindrical expanding in which several layers of filter paper are located (for example, f1 in Figure 1. 5. Restrictor hole. 6. Tubes for extract sampling $a, b, c, d$. 7 . Radial channels for removing the extract to restrictor. 
of which is shown in Figure 1 and Figure 2, has been carried as follows:

- A filter paper with the applied and dried original extract in the amount of 0.2 $\mathrm{ml}$ or more was placed in the reactor;

- The upper flange of the reactor had a temperature $T_{1}=35^{\circ} \mathrm{C}$, the bottom flange $-T_{2}=45^{\circ} \mathrm{C}$;

- The pressure of carbon dioxide in the reactor was set at a level of 20.0 MPa;

- The extract holding in the reactor lasted for 0.5 hours;

- The extract discharge was carried out for about $1 \mathrm{~min}$ from the initial pressure to atmospheric.

The extract was removed through a device for extract removing from the reactor 14, the inlet holes of the tubes of which were located at specified distances from the bottom flange of the reactor.

In the first series of experiments, the lengths of the tubes were $a-30 \mathrm{~mm}$, $b-60 \mathrm{~mm}, c-90 \mathrm{~mm}, d-120 \mathrm{~mm}$.

In the second series of experiments: $a-60 \mathrm{~mm}, b-90 \mathrm{~mm}, c-120 \mathrm{~mm}$, and $d-150 \mathrm{~mm}$.

\section{Experimental Results of SFE - $\mathrm{CO}_{2}$ of Molybdenum Isotopes}

To assess the accuracy of measuring the content of molybdenum isotopes in experimental samples the test studies of the molybdenum isotope content in the initial solution of molybdenum in acetylacetone were carried out.

Table 1 shows the data on the natural content of Mo isotopes: column 2reference data; column 3-data obtained by the mass spectrometer ICP-MS ELEMENT 2 for the initial solution of molybdenum in acetylacetone.

A comparison of the data in Table 1 indicates that the reference data and the data obtained by the mass spectrometer completely correspond to the content of molybdenum isotopes in the initial solution.

The samples obtained as a result of SFE- $\mathrm{CO}_{2}$ extraction were analyzed for the content of molybdenum isotopes using the spectra of a high-resolution mass spectrometer with ionization in inductively coupled plasma ICP-MS ELEMENT $2[20]$.

Table 1. The content of molybdenum isotopes: natural (2) in the initial solution (3).

\begin{tabular}{ccc}
\hline \multirow{2}{*}{ Mo isotopes } & 2 & 3 \\
\cline { 2 - 3 } & Natural content, \% & Content in the initial solution, \% \\
\hline 92 & 14.84 & $14.8063 \pm 0.1429$ \\
94 & 9.25 & $9.31356 \pm 0.19903$ \\
95 & 15.92 & $15.90653 \pm 0.19113$ \\
96 & 16.68 & $16.62644 \pm 0.19945$ \\
97 & 9.55 & $9.64547 \pm 0.17835$ \\
98 & 24.13 & $24.01053 \pm 0.44074$ \\
100 & 9.63 & $9.69117 \pm 0.0978$ \\
\hline
\end{tabular}




\section{Study of the Content of Molybdenum Isotopes}

As a result of SFE- $\mathrm{CO}_{2}$ of the initial solution 4 sets of filter paper in the form of 5 circles of the diameter of $3 \mathrm{~mm}$ were obtained. Each set of filter paper contained trace amounts of extract. The content of molybdenum isotopes in each set of filter paper corresponded to that established during the extract holding for 0.5 hours at the reactor heights corresponding to the length of the tubes for extract sampling $a, b, c, d$ (see 6, Figure 2).

Four SFE- $\mathrm{CO}_{2}$ of the initial solution were carried out in the first series of experiments. The lengths of the tubes of the device for extract removing from the reactor were: $a-30 \mathrm{~mm}, b-60 \mathrm{~mm}, c-90 \mathrm{~mm}$, and $d-120 \mathrm{~mm}$.

Two SFE- $\mathrm{CO}_{2}$ of the initial solution were carried out in the second series of experiments. One series (Experiment 5) was not considered due to the large measurement error. In this series of experiments the lengths of the tubes of the device for extract removing from the reactor were: $a-60 \mathrm{~mm}, b-90 \mathrm{~mm}$, $c-120 \mathrm{~mm}$, and $d-150 \mathrm{~mm}$.

To analyze the content of molybdenum isotopes using the mass spectrometer ICP-MS ELEMENT 2 the obtained filter paper samples were dissolved in 2\% $\mathrm{HNO}_{3}$ and mixed for 15 hours on a vibrating mixer. 16 measurements were carried out for each sample. The results obtained after statistical processing are presented in Tables 2-6.

Table 2. The concentration of molybdenum in solutions after extraction measured in the minimum amount required for analysis.

\begin{tabular}{cccccccccc}
\hline $1 / 3$ & $1 / 6$ & $1 / 9$ & $1 / 12$ & $2 / 3$ & $2 / 6$ & $2 / 9$ & $2 / 12$ & \multicolumn{2}{c}{$\begin{array}{c}\text { The filter in the } \\
\text { reactor after } \\
\text { extraction }\end{array}$} \\
1.3 & 1.0 & 2.2 & 1.7 & 3.6 & 14.7 & 17.1 & 9.9 & 4 " & $4^{\prime \prime}$ \\
$3 / 3$ & $3 / 6$ & $3 / 9$ & $3 / 12$ & $4 / 3$ & $4 / 6$ & $4 / 9$ & $4 / 12$ & 4 & 2.73 \\
4.60 & 1.65 & 1.31 & 2.98 & 3.15 & 1.57 & 1.0 & 1.71 & 111.69 & $6 / 2$ \\
$5 / 6$ & $5 / 9$ & $5 / 12$ & $5 / 15$ & $6 / 6$ & $6 / 9$ & $6 / 12$ & $6 / 15$ & 6 & $6^{\prime \prime}$ \\
2.32 & 1 & 1.20 & 3.60 & 5.04 & 2.18 & 9.05 & 7.56 & 637.13 & - \\
\hline
\end{tabular}

1) Fraction numerator-experiment number, fraction denominator-tube length in $\mathrm{cm}$; 2) The numbers with strokes correspond to the number of the experiment; 3) '-the area of application the molybdenum solution on the filter paper; 4) "-the area without application the molybdenum solution on the filter paper.

Table 3. The content of molybdenum isotopes in Experiment 1.

\begin{tabular}{ccccccccc}
\hline $\begin{array}{c}\text { Mo } \\
\text { isotopes }\end{array}$ & $1 / 30$ & $\begin{array}{c}\text { RSD, } \\
\%\end{array}$ & $1 / 60$ & $\begin{array}{c}\text { RSD, } \\
\%\end{array}$ & $1 / 90$ & $\begin{array}{c}\text { RSD, } \\
\%\end{array}$ & $1 / 120$ & $\begin{array}{c}\text { RSD, } \\
\%\end{array}$ \\
\hline 92 & 14.87344 & 1.08 & 14.74892 & 0.65 & 14.74912 & 1.08 & 14.50425 & 0.44 \\
94 & 9.84251 & 0.72 & 9.73834 & 1.19 & 9.75131 & 0.64 & 9.41772 & 0.95 \\
95 & 15.44919 & 0.78 & 15.53862 & 0.95 & 15.52508 & 1.2 & 15.81638 & 0.13 \\
96 & 16.5744 & 0.9 & 16.48552 & 0.92 & 16.61266 & 0.33 & 16.55638 & 0.96 \\
97 & 9.45942 & 0.95 & 9.53036 & 1.11 & 9.52119 & 0.45 & 9.56751 & 0.85 \\
98 & 24.12553 & 0.41 & 24.20484 & 0.19 & 24.0971 & 1.12 & 24.33825 & 1.42 \\
100 & 9.67552 & 0.65 & 9.75341 & 0.81 & 9.74373 & 0.54 & 9.7996 & 1.06 \\
\hline
\end{tabular}


Table 4. The content of molybdenum isotopes in Experiment 2.

\begin{tabular}{ccccccccc}
\hline Mo isotopes & $2 / 30$ & RSD, \% & $2 / 60$ & RSD, \% & $2 / 90$ & RSD, \% & $2 / 120$ & RSD, \% \\
\hline 92 & 14.46862 & 1.32 & 14.22175 & 1.49 & 14.34716 & 0.83 & 14.37421 & 0.98 \\
94 & 9.27374 & 0.58 & 9.04006 & 0.69 & 8.99798 & 0.49 & 9.10263 & 1.15 \\
95 & 15.74411 & 0.73 & 15.88169 & 1.15 & 15.7823 & 0.81 & 15.77922 & 0.62 \\
96 & 16.69692 & 1.79 & 16.71459 & 0.32 & 16.73006 & 1.45 & 16.81411 & 0.7 \\
97 & 9.58954 & 0.73 & 9.56931 & 1.27 & 9.56703 & 0.73 & 9.64366 & 0.79 \\
98 & 24.32874 & 0.85 & 24.72824 & 0.85 & 24.7716 & 0.91 & 24.46282 & 0.7 \\
100 & 9.89837 & 0.93 & 9.84434 & 0.5 & 9.804 & 0.68 & 9.82342 & 0.76 \\
\hline
\end{tabular}

Table 5. The content of molybdenum isotopes in Experiment 3.

\begin{tabular}{ccccccccc}
\hline Mo isotopes & $3 / 30$ & RSD, \% & $3 / 60$ & RSD, \% & $3 / 90$ & RSD, \% & $3 / 120$ & RSD, \% \\
\hline 92 & 13.70071 & 1.92 & 13.98191 & 1.91 & 14.00468 & 1.43 & 14.13914 & 2.49 \\
94 & 9.22078 & 1.38 & 9.24747 & 4.18 & 9.36752 & 2.59 & 9.37755 & 1.04 \\
95 & 15.63093 & 2.9 & 15.71258 & 2.57 & 15.9451 & 3.63 & 15.96291 & 0.76 \\
96 & 16.84187 & 2.85 & 16.55985 & 2.12 & 16.80422 & 2.21 & 16.69741 & 2.47 \\
97 & 9.92077 & 1.71 & 9.70158 & 3.52 & 9.59672 & 1.59 & 9.69677 & 1.69 \\
98 & 24.68899 & 1.55 & 24.75151 & 2.42 & 24.4066 & 0.77 & 24.31471 & 1.61 \\
100 & 9.99596 & 0.44 & 10.0451 & 1.58 & 9.87515 & 1.75 & 9.8115 & 2.85 \\
\hline
\end{tabular}

Table 6. The content of molybdenum isotopes in Experiment 4.

\begin{tabular}{crrrrrrrrr}
\hline Mo isotopes & $4 / 30$ & RSD, \% & $4 / 60$ & RSD, \% & $4 / 90$ & RSD, \% & $4 / 120$ & RSD, \% \\
\hline 92 & 13.85738 & 3.09 & 14.13625 & 3.57 & 14.06521 & 1.9 & 14.14556 & 2.72 \\
94 & 9.33645 & 3.19 & 9.42547 & 2.06 & 9.6107 & 1.59 & 9.79968 & 3.04 \\
95 & 15.88894 & 1.62 & 15.87809 & 1.67 & 15.80871 & 1.24 & 15.74884 & 1.66 \\
96 & 16.80749 & 2.91 & 16.62098 & 1.59 & 16.84385 & 1.64 & 16.75888 & 0.7 \\
97 & 9.68436 & 2.86 & 9.77164 & 1.46 & 9.53777 & 2.27 & 9.51521 & 1.69 \\
98 & 24.55187 & 1.99 & 24.15933 & 0.88 & 24.25568 & 1.8 & 24.24956 & 1.7 \\
100 & 9.87351 & 2.68 & 10.00823 & 2.39 & 9.87809 & 3.34 & 9.78227 & 1.76 \\
\hline
\end{tabular}

The data on the content of molybdenum isotopes in experiments 1, 2, 3, 4 are presented in Tables 3-6. RSD, \%-relative standard deviation indicates the relative standard deviation of the measured value from its average value.

To determine the content of molybdenum isotopes near the bottom flange of the reactor in experiment 4 the molybdenum content on filter paper placed in the reactor containing the initial extract was analyzed after extraction. We analyzed the content of molybdenum isotopes in the area where the molybdenum 
solution was not applied to the filter paper (column 4' of 'Table 7) and in the area of applying the initial molybdenum solution to the filter paper (column 4" of Table 7).

Diagrams of the dependence of the deviation of the average molybdenum isotope content from the natural one depending on the height of the extract sampling are presented in Figures 3(a)-(g). The measured points are connected using cubic spline interpolation of the embedded MathCAD program [21].

When plotting the graphs we averaged the values of isotopes distribution at levels $a-30 \mathrm{~mm}, b-60 \mathrm{~mm}, c-90 \mathrm{~mm}, d-120 \mathrm{~mm}$ and added to them the data of isotopes distribution near the bottom flange of the reactor and at heights of 12 $\mathrm{cm}$ (experiment 4) and $15 \mathrm{~cm}$ (experiment 6) from it.

In the figures, the confidence interval of measuring the isotope content is specified by two horizontal segments located above and below the measured point.

Verification of the spectral method for determining the content of Mo isotopes using mass spectrometer ICP-MS ELEMENT 2 for the initial solution of molybdenum in acetylacetone showed its applicability.

The amount of molybdenum in the extract was sufficient to evaluate its isotope content.

From the analysis of Figure 3, it follows that during the holding of the extract in the reactor for 0.5 hours at a temperature gradient of $\gamma=\left(T_{2}-T_{1}\right) / L=10 / 21.8 \sim 0.46{ }^{\circ} \mathrm{C} / \mathrm{cm}$ the content of Mo isotopes depending on the reactor height differs from the natural one.

This is confirmed by the data in graphs presented in Figure 3.

The content of the isotope 92 (Figure 3(a)) is depleted in comparison with the natural content at the reactor height $0 \mathrm{~cm} \leq \mathrm{z} \leq 15 \mathrm{~cm}$. With increasing the sampling height the deviation of the content of the isotope 92 from the natural one decreases from $1 \%$ to $-0.66 \%$.

In Figure 3(b), the content of the isotope 94 relative to the natural one is enriched, except for the heights of $0 \mathrm{~cm}$ and $6 \mathrm{~cm}$, where its content corresponds

Table 7. The distribution of molybdenum isotopes after extraction on filter paper with the initial solution in experiment 4.

\begin{tabular}{cccccc}
\hline Mo isotopes & Natural distribution, $\%$ & $4^{\prime}$ & RSD, \% & $4^{\prime \prime}$ & RSD, \% \\
\hline 92 & 14.84 & 14.37487 & 0.87 & 13.75123 & 3.28 \\
94 & 9.25 & 9.0918 & 0.35 & 9.37635 & 4.31 \\
95 & 15.92 & 15.85231 & 0.25 & 16.0536 & 2.39 \\
96 & 16.68 & 16.7943 & 0.61 & 16.75879 & 1.38 \\
97 & 9.55 & 9.51841 & 0.3 & 9.7736 & 2.27 \\
98 & 24.13 & 24.68542 & 0.94 & 24.45131 & 1.14 \\
100 & 9.63 & 9.68271 & 0.75 & 9.83513 & 2.54 \\
\hline
\end{tabular}




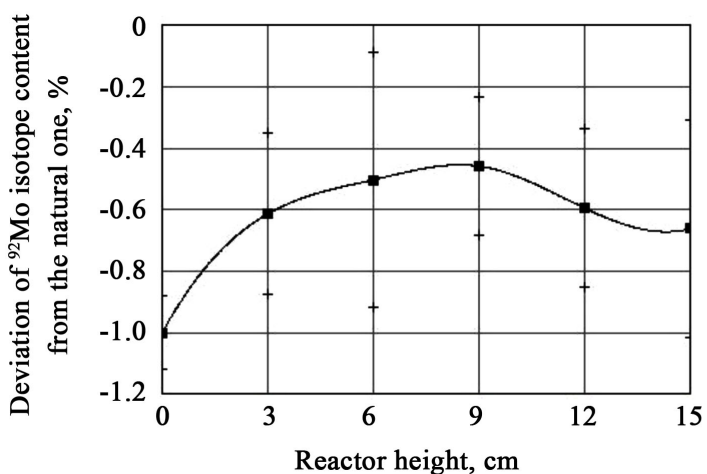

(a)

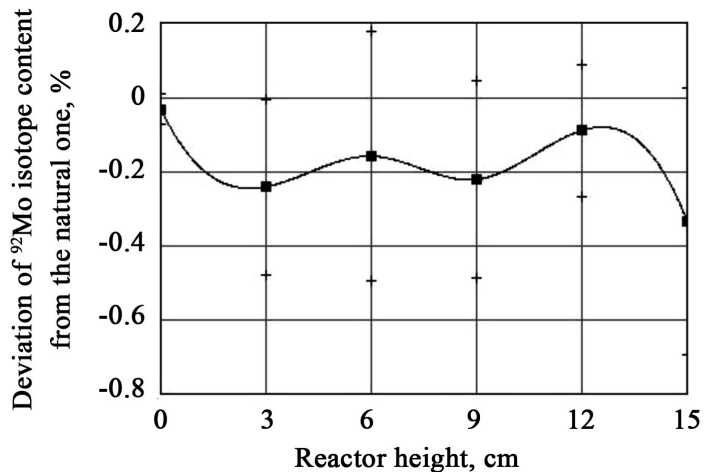

(c)

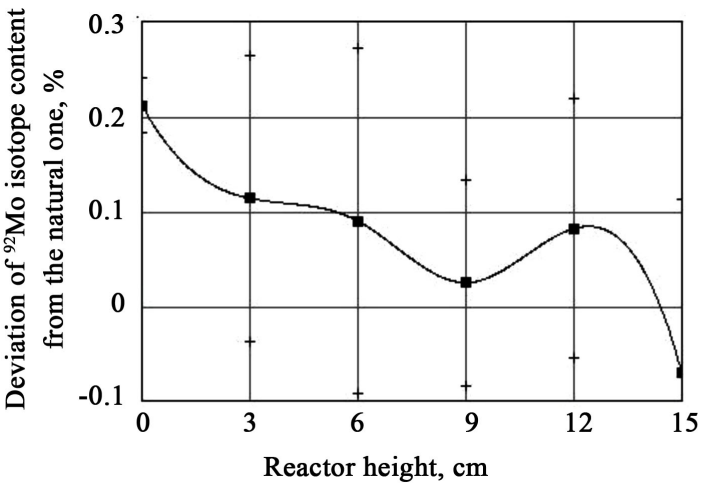

(e)

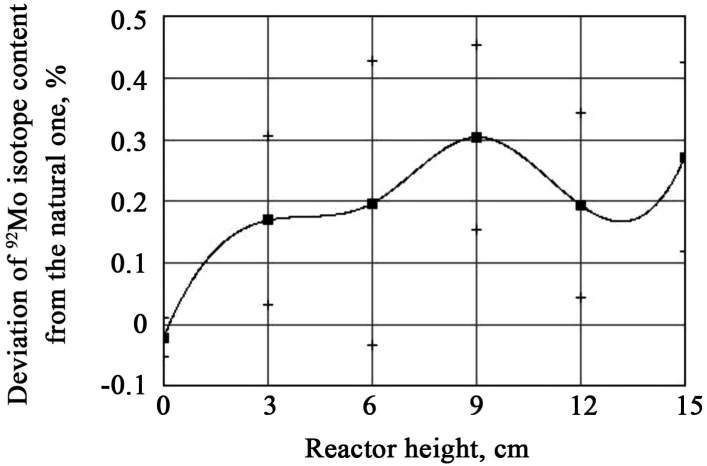

(b)

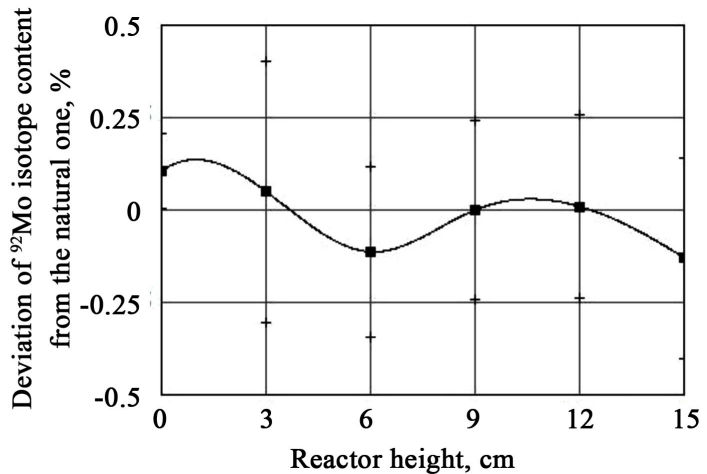

(d)

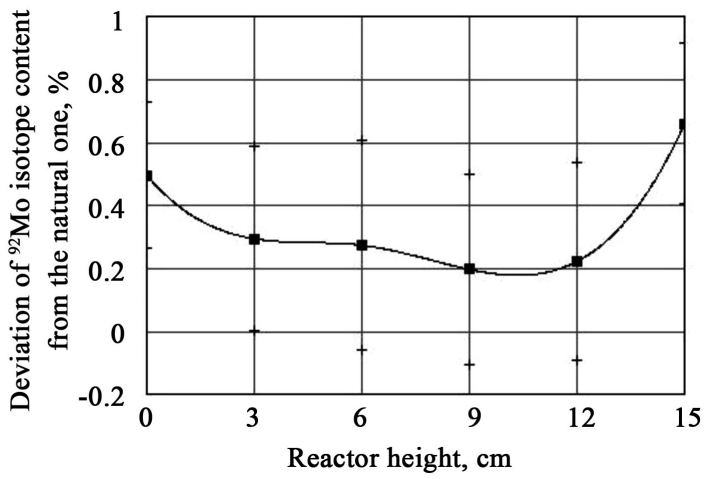

(f)

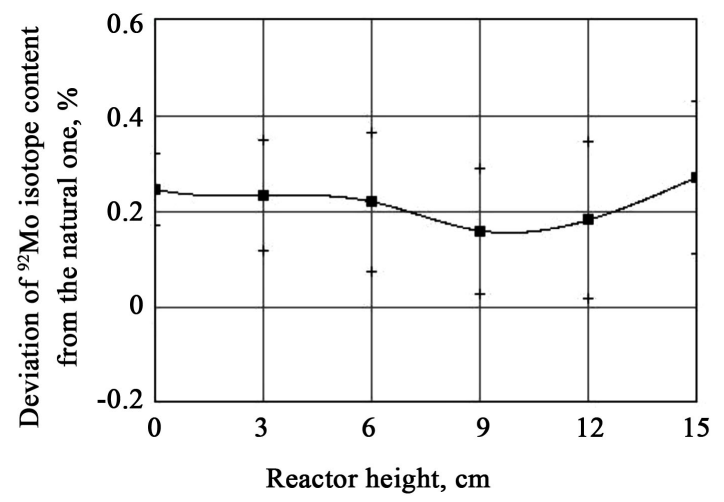

(g)

Figure 3. (a)-(g) Dependence of deviation of the average molybdenum isotope content from the natural one depending on the height of sampling. 
to the natural one. The enrichment value increases with the sampling height from $+0.17 \%$ at a height of $3 \mathrm{~cm}$ to $+0.27 \%$ at a height of $15 \mathrm{~cm}$.

In Figure 3(c), the content of the isotope 95 corresponds to the natural one, except for the mark of $3 \mathrm{~cm}$ depending on the reactor height, where its content is $0.24 \%$ lower than the natural one.

In Figure 3(d), the content of the isotope 96 at the bottom of the reactor is enriched $(+0.1 \%)$. At other points depending on the reactor height the content of the isotope 96 corresponds to the natural one.

In Figure 3(e), the content of the isotope 97 at the bottom of the reactor is enriched $(+0.21 \%)$ and at other points depending on the reactor height its content corresponds to the natural one.

In Figure 3(f), the content of the isotope 98 at the bottom of the reactor is enriched (+0.5\%). With an increase in the height of the reactor at a level of $3 \mathrm{~cm}$ its enrichment is $+0.29 \%$ of the natural one. Then the content of the isotope 98 depending on the reactor height corresponds to the natural one and at a height of $15 \mathrm{~cm}$ it increases to a value of $+0.66 \%$.

In Figure 3(g), the content of the isotope 100 is higher than the natural one at the reactor height $0 \mathrm{~cm} \leq \mathrm{z} \leq 15 \mathrm{~cm}$ by an average of $+0.2 \%$. With increasing the reactor height its content increases oscillating in comparison with the natural one by a value from $+0.24 \%$ at the bottom of the reactor to $+0.27 \%$ at a height of $15 \mathrm{~cm}$.

As follows from the above, the distribution of molybdenum isotopes in the reactor at heights of $15 \mathrm{~cm} \leq \mathrm{z} \leq 21.8 \mathrm{~cm}$ was not determined. However, in reliance on the conservation of the total mass of molybdenum and the natural percentage of its isotopes it follows that the deviation of the content of molybdenum isotopes, integrated over the entire fluid volume, from the natural one should be equal to zero. Based on this statement the diagrams of deviation of the distribution of molybdenum isotopes from the natural one depending on the reactor height reactor were calculated. These diagrams are presented in Figure 4. Horizontally the height of the reactor is indicated, the figures in the upper left corner of each diagram indicate the molybdenum isotope number.

It follows from Figure 4 that at the specified parameters of SFE- $\mathrm{CO}_{2}$ of molybdenum complexes the lightest isotope 92 is in enriched state near the upper flange $\mathrm{z}=21.8 \mathrm{~cm}$ and the heaviest 100 and presumably 98 are enriched and occupy a space of $0 \mathrm{~cm} \leq \mathrm{z} \leq 15 \mathrm{~cm}$.

The isotope 94 in the enriched state is concentrated in the range of $3 \mathrm{~cm} \leq \mathrm{z} \leq$ $15 \mathrm{~cm}$.

The isotope 95, like the isotope 92, is located near the upper flange $z=21.8$ $\mathrm{cm}$.

Isotopes 96,97 are enriched near the bottom flange of the reactor $\mathrm{z}=0 \mathrm{~cm}$.

It should be noted that such a distribution will not be preserved at a longer holding. Therefore, determination of a holding time is important to achieve maximum enrichment at target isotope extraction. 

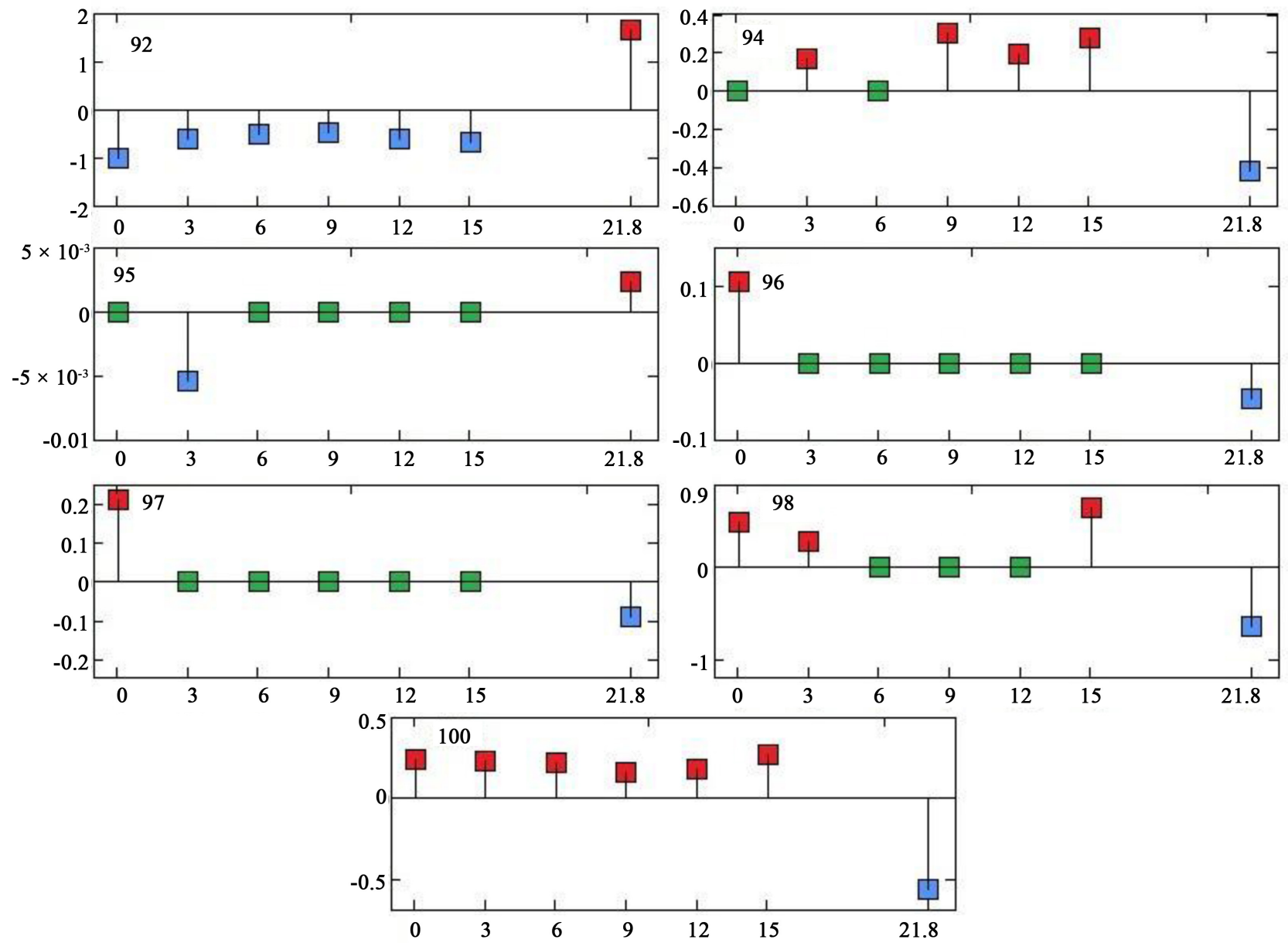

Figure 4. Diagrams of deviation of distribution of molybdenum isotopes from the natural one depending on the reactor height. Red and blue markers correspond respectively to increased or decreased content of the molybdenum isotope relative to the natural content. A green marker indicates that there is no deviation of molybdenum isotope content from the natural one.

Thus, the conducted experimental studies of supercritical fluid extraction with carbon dioxide in a vertical gradient temperature field of the molybdenum complex showed a deviation of its isotopic content from the natural one depending on the sampling height for a given extract holding time.

\section{Conclusions}

The extraction of isotopes of molybdenum complexes by the SFE- $\mathrm{CO}_{2}$ method was studied in this paper. A series of experiments were carried out on the extraction of molybdenum isotope complexes in the updated SFE-U installation at a constant initial pressure of $\mathrm{P}=20 \mathrm{MPa}$ and constant temperatures of the bottom $\mathrm{T}_{2}=45^{\circ} \mathrm{C}$ and upper $\mathrm{T}_{1}=35^{\circ} \mathrm{C}$ flanges of the extraction chamber. In each of the experiments, the content of molybdenum isotopes varied depending on the height of eluent sampling from the extraction chamber.

Based on the experiments the following conclusions can be drawn:

A deviation of the content of Mo isotopes from natural one in the extract at a temperature gradient between the bottom and upper flanges of the reactor of 
$0.46^{\circ} \mathrm{C} / \mathrm{cm}$ at the extract holding for 0.5 hours and the pressure relief in the reactor from $20 \mathrm{MPa}$ to atmospheric within $1 \mathrm{~min}$ was detected;

The content of the isotope 92 is depleted in comparison with the natural content at the height of the reactor $0 \mathrm{~cm} \leq \mathrm{z} \leq 15 \mathrm{~cm}$. With increasing the sampling height the deviation of the content of the isotope 92 from the natural one decreases from $1 \%$ to $-0.66 \%$

The content of the isotope 94 is enriched relatively natural except for a height of $0 \mathrm{~cm}$ and $6 \mathrm{~cm}$ where its content corresponds to the natural. The enrichment value increases with the sampling height from $+0.17 \%$ at a height of $3 \mathrm{~cm}$ to $+0.27 \%$ at a height of $15 \mathrm{~cm}$.

The content of the isotope 95 corresponds to the natural one except for the height mark of the reactor $3 \mathrm{~cm}$ where its content is $0.24 \%$ lower than the natural one.

The content of isotope 96 at the bottom of the reactor is $+0.1 \%$ higher than natural one. At other points, the content of the isotope 96 corresponds to the natural one depending on the reactor height.

The content of the isotope 97 at the bottom of the reactor is higher than natural by $+0.21 \%$ and at other points depending on the reactor height its content corresponds to the natural one.

The content of the isotope 98 at the bottom of the reactor is higher than natural by $+0.5 \%$. With an increase in the height of the reactor at a level of $3 \mathrm{~cm}$, its enrichment is $+0.29 \%$ of the natural. With increasing the height of sampling the content of the isotope 98 corresponds to the natural one and at a height of 15 $\mathrm{cm}$, it increases to a value of $+0.66 \%$.

At reactor heights of $0 \mathrm{~cm} \leq \mathrm{z} \leq 15 \mathrm{~cm}$ the content of the isotope 100 is higher than the natural one by an average of $+0.2 \%$. Its value changes in comparison with the natural content oscillating at the level of $+0.2 \%$. Moreover, it is higher than the natural content by a value of $+0.24 \%$ at the bottom of the reactor and by $+0.27 \%$ at a height of $15 \mathrm{~cm}$.

Analysis of the content of molybdenum isotopes at the entire height of the reactor has shown that the lightest isotope 92 is in an enriched state near the upper flange $\mathrm{z}=21.8 \mathrm{~cm}$ and the heaviest 100 and presumably 98 are enriched and occupy a space of $0 \mathrm{~cm} \leq \mathrm{z} \leq 15 \mathrm{~cm}$.

The isotope 94 in the enriched state is concentrated in the range of $3 \mathrm{~cm} \leq \mathrm{z} \leq$ $15 \mathrm{~cm}$.

Isotope 95 as isotope 92 is located near the upper flange at $\mathrm{z}=21.8 \mathrm{~cm}$.

Isotopes 96,97 are enriched near the bottom flange of the reactor at $\mathrm{z}=0 \mathrm{~cm}$.

\section{Conflicts of Interest}

The authors declare no conflicts of interest regarding the publication of this paper.

\section{References}

[1] Ma, B.M. (1987) Materialy yadernykh energeticheskikh ustanovok: Per. s angl. M.: 
Energoatomizdat, $408 \mathrm{~s}$.

[2] Obogashcheniye urana (1983) Pod red. S. Villani: Per. s angl. Pod red. I.K. Kikoina. M.: Energoatomizdat, $320 \mathrm{~s}$.

[3] Longeneker, D. (1987) Lazernoye obogashcheniye urana v SSHA. Atomnaya tekhnika za rubezhom, 3, 32-34.

[4] Katz, J.J., Seaborg, G.T. and Morss, L.R. (1986) The Chemistry of Actinide Elements, Volume 1. 2nd Edition, Chapman and Hall, London, 525.

https://doi.org/10.1007/978-94-009-4077-2

[5] Denniss, I. and Jeapes, A. (1996) In: The Nuclear Fuel Cycle: From Ore to Waste. Oxford University Press, Oxford, 7, 123.

[6] Patton, F.S., Gudzhin, D.M. and Griffits, V.L. (1966) Yadernoye goryucheye na osnove obogashchennogo urana, Per. s ang. Pod red. N.P. Galkina, M. Atomizdat, 290 s.

[7] Neklyudov, I.M., Azarenkov, N.A., Borts, B.V., Odeychuk, N.P., Skoromnaya, S.F. and Tkachenko, V.I. (2008) Sravneniye i analiz sushchestvuyushchikh metodov izvlecheniya urana i yego soyedineniy iz materialov atomnoy energetiki. NNTS, Khar'kov.

[8] Zimmermann, R. (2007) Nuclear Medicine: Radioactivity for Diagnosis and Therapy. La Médecinenucléaire. La radioactivité au service du diagnostic et de la thérapie, EDP Sciences, Lez-Yulis, 173 p.

[9] Krylov, V.V. (2012) Izotopy dlya yadernoy meditsiny. Sostoyaniye i perspektivy. Radiatsionnaya onkologiya i yadernaya meditsina, 1, 80-84.

[10] http://dozor.kharkov.ua/news/nauka/1143752.html

[11] Grinev, B.V. Gektin, A.V., Demin, A.V., Lyubinskiy, V.R. and Makeyev, S.S. (2005) Spetsializirovannaya dlya diagnostiki golovnogo mozga tomograficheskaya gamma kamera “OFEKT-3”. Nauka Ta Ínnovatsíi, 2, 75-79.

[12] Bekman, I.N. (2015) Radiokhimiya. V 2 t. T. 1. Fundamental'naya radiokhimiya: Uchebnik i praktikum dlya akademicheskogo bakalavriata, M.: Izdatel'stvo Yurayt, $473 \mathrm{~s}$.

[13] Guk, I.S., Kononenko, S.G. and Peyev, F.A. (2010) O vozmozhnosti proizvodstva diagnosticheskogo meditsinskogo izotopa tekhnetsiya ${ }^{99} \mathrm{M}$ v Ukraine' Vestnik Khar' kovskogo universiteta, seriya fizicheskaya: "Yadra, chastichki, polya", 916, 117-126.

[14] Fedorenko, Z.P., Hulak, L.O., Mykhaylovych, Y.Y., Horokh, YE.L., Ryzhov, A.YU., Sumkina, O.V. and Kutsenko, L.B. (2019) Byuleten' natsional'noho kantser-reyestru Ukrayiny. Kyiv, 20. http://ncru.inf.ua/publications/BULL 20/index.htm

[15] Goletskiy, N.D., Mashirov, L.G. and Zil’berman, B.Y.A. (2010) Ekstraktsiya molibdena rastvorami tributilfosfata iz peresyshchennykh azotnokislykh rastvorov. Radiokhimiya, 52, 155-161.

[16] Borts, B., Palamarchuk, A., Tkachenko, V. and Skoromnaya, S. (2016) The Study of Supercritical Extraction of Complexes of Molybdenum with Carbon Dioxide. Eastern-European Journal of Enterprise Technologies, No. 84, 57-63. https://doi.org/10.15587/1729-4061.2016.85112

[17] Borts, B.V., Kazarinov, Y.G., Neklyudov, I.M., Ivanova, S.F. and Tkachenko, V.I. (2015) Prostranstvenno-neodnorodnoe raspredelenie izotopa uran-235 pri sverkhkriticheskoy flyuidnoy ekstraktsii dioksidom ugleroda v gradientnom pole temperatur. VANT, Ser. Materialovedenie i novye materialy, 4, 81-91.

[18] Borts, B.V., Ivanova, S.F. and Tachenko, V.I. (2016) Model' opisaniya ekstraktsii 
kompleksov izotopov uran-235 i uran-238 v podogrevaemom snizu sloe sverkhkriticheskogo dioksida ugleroda. VANT, Ser. Materialovedenie i novye materialy, 3 , $50-60$.

[19] Borts, B.V., Bulavin, L.A., Skoromnaya, S.F. and Tkachenko, V.I. (2020) Supercritical Fluid Extraction of Molybdene Complexes and Its Isotopes with Carbon Dioxide. PAST, 5.

[20] Muzgin, V.N., Yemel'yanova, H.H. and Pupyshev, A.A. (1998) Mass-spektrometriya $\mathrm{s}$ induktivno-svyazannoy plazmoy-novyy metod v analiticheskoy khimii. Analitika i kontrol'. 3-4. 3-25.

[21] http://radiomaster.ru/cad/mc12/glava 13/index04.php 